\title{
The Effects of Westernization Efforts on the Turkish Education System ${ }^{1}$
}

\author{
Seyithan DEMİRA $\breve{G}^{2}$, Muhammad KHALIFA
}

\begin{tabular}{l} 
ARTICLE INFO \\
\hline Article History: \\
Received 01.12.2019 \\
Received in revised form \\
12.04.2020 \\
Accepted Tarih girmek için \\
burayı tiklatın. \\
Available online 01.07 .2020
\end{tabular}

\begin{abstract}
Westernization refers to the establishment of a system based on science and technology in the life of a society and encourages developing countries to learn and then use what the West has found in science, technology, human rights, prosperity, and art. In this paper, we have argued the effects of Westernization efforts and how the power holding groups use these efforts on their behalf to have authority over governmental institutions and change the education policy of Turkey according to their ideology. Quijano's notion of Coloniality was used to explain how people, who had a control over governmental authorities used Westernization to impose their own ideology in Turkish education policy. In the paper, firstly, we argued why the conflicts due Westernization arise between pro-Westerners and anti-Westerners and how this situation effects the education policy of some societies in the world. Second, we discussed the Westernization efforts made in Turkey. Third, we explained criticism towards Westernization since the Ottoman period. Lastly, we argued how the conflicts between pro-Westerners and anti-Westerners ended up in military coups.
\end{abstract}

C IJERE. All rights reserved

Keywords: ${ }^{4}$

Westernization, Turkish Education, Military Coups, Anti-Westerners.

INTRODUCTION

Westernization efforts have influenced the education systems of many nations throughout the world. Such efforts have impacted education in recent Turkish history as well. It is argued here that Westernization has pushed forth a very narrow and non-Indigenous way of knowing and learning in Turkish history, and it has been assumed that this has been beneficial for Turks. Because of promises of Modernity (Mignolo, 2009; Quijano, 2000)-which positioned science and technology as the way to make Turkey internationally competitive-Turkish elite and educators moved quickly to adopt Western epistemologies within educational growth. But, for better or worse, this has come at the expense of Turkish and Islamic epistemologies within education and society. In this article, the tension between Westernization and traditional/indigenous Turkish education as equitable choice options is not discussed. Rather, it is understood that Turkish leaders at moments in history have leaned more heavily toward Westernization, and thus the "power" has been primarily held by those hoping to standardize and normalize Western approaches to education.

The power permeates every aspects of life, today. For example, the people in power use schools as another agent of power (Foucault, 2003). They use schools to domesticate students for their political ideologies (İnal, 1996; Mayo, 2011). So, the schools are used to become propaganda instrument by parties in power (Ferrer, 2014). That is why schooling may be useful to some students and not the same to others (Bloom, 1995). School leaders need to take crucial steps to create positive school settings that would be beneficial for all students because people, who have controls over education systems may create extreme opposite worldviews among students, thus the society.

Due to discussions on education system, Turkish society is divided into two very opposite camps: One is labeled under the old views and the other is labeled under the new views of the education system Aygün (2014). Turkish society has witnessed such arguments and fights between pro-Westerners and the conservatives (anti- Westerners) as well. The leaders of pro-Westerners support the new views of the education system, while the conservatives support the old views of the education system (Kizılcelik, 2015). In this case, it is important to understand Westernization movement and its effects in the society.

\footnotetext{
${ }^{1}$ This paper is prepared during the post-doctoral studies of corresponding author at the University of Minnesota-Twin Cities ${ }^{2}$ Corresponding e-mail: seyithandemirdag@gmail.com, orcid.org/0000-0002-4083-2704, Zonguldak Bulent Ecevit University ${ }^{3}$ e-mail: khalifam@umn.edu, orcid.org/0000-0002-0369-2271, University of Minnesota-Twin Cities
} 
Because of its colonial ties, the efforts of Westernization had various implications based on how it was perceived or practiced by the people of different societies. For example, in Mexico, the effects of Westernized practices are quite oppressive in the education system. Due to this reason, it is very challenging to enable educational approaches, which include the worldviews of the Indigenous (non-Western) people of Mexico. For example, in 2011, there was an attempt to enable a program called Indigenous Initial Education program in Mexico. The main goal of the program was to initiate community appropriate bilingual programs, prioritize communal values and Indigenous socialization practices (Meyer, 2017). As the federal school policy is under the heavy effect of the Western influenced views in education, this program have to deal with the intense oppositional pressures of the people in Mexico today (Rogoff, 2003). Similar problems associated with the practices of Westernization exist in Muslim nations as well.

For many centuries, education in Muslim countries included the teachings of Islam. Such education was actually Quranic education as it mainly aimed to provide righteous conduct and correct knowledge of Allah (God). In the early centuries of Islam, the education of youth was based on the thoughts of the religion and provided in places such as mosques. So, basically this type of education was endowed by private parties and organized in local areas. The teachings of Islam were the main focus of this education system throughout the centuries (Cook, 2000).

With the colonial expansion of the West into the Muslim world during the 19th century, Muslim nations were for the first time introduced to the worldviews of the West and secular thought. A conflict was initiated between pro-Westerners and anti- Westerners as this situation opened doors for practicing the praxis of Westernization and modernity in many aspects of daily life of Muslims, who were accustomed only to the traditional teachings of Islam. Muslims around the world had difficulty to justify this new worldview and secularism in different aspects of their life such as religion, politics, and education (Cook, 2000). Even though various permutations of Islamic and Western education systems were employed to resolve the conflict between pro-Westerners and anti-Westerners, the issue still remains strong in Muslim nations, today.

Westernization had an effect on Muslim world due to the ideology of the West and the practices of modern schooling. Since the mid-nineteenth century, obvious changes in many areas including in education occurred. Education systems of Muslim world have been impacted by the conflict between by orientalist methods and modernist methods (Cook, 2000). After so called modern schooling approaches, the views of local or Indigenous populations were denied as secular educational paradigms were imported from Western societies. This situation created conflicts between local or non-Western people and those in administrative positions. In many cases, centralized governments took actions to control confrontations yet imposing their own worldviews, which were aligned with Western values in the education system by oppressing the Indigenous ones (Herrera, 2004).

In a study, the effects of westernization was examined on Indian Muslims in South Africa. The results suggested that especially South African Indian Muslims regarded westernization as a negative influence to their social life (Schoombee \& Mantzaris, 1986). In another study, research was conducted on Westernization movement in Egypt. The result showed that there was a polarization of power between pro-Westerners and anti-Westerners. The dissemination of power between the elites of both groups were unequal as the proWesterners, who were a small group but powerful in politics and in development of education system. The current westernized education system in Egypt caused indigenous people to question and oppose the new education system. They protested the new system by turning to alternative forms of education to preserve the indigenous and Islamic values of Egypt. In that sense, they were inclined to send their school-age children to private Islamic schools rather than to the public ones. Some children were even sent to free courses provided by Islamic charitable organizations (Cook, 2000).

As a Muslim nation, the movement of Westernization in Turkey have its supporters and protesters. The conflict between both groups have started during Ottomans and continues even today. Historically, Turkey has never been fully colonized by any of the imperial powers. However, under the movement of modernization, one may think that due to the efforts of Westernization, the country was semi-colonized externally and internally on its education, politics, ideology, and worldviews. In that sense, the direct intervention of the West may be considered as external colonialism. In this paper, we make use of Quijano's 
notion of Coloniality to mean the lasting impact that Colonialism has on former colonies, as well as nations that have not been colonized. Based on Quijano's theory, the colonial power includes four domains: control of authority, control of economy, exploitation of labor, and control of gender and sexuality (Mignolo, 2009). More specific to this paper, we focus mainly on the domain called the control of authority, which refers to how power holding groups such as pro-Westerners and anti-Westerners in Turkish politics and education have a control on all governmental and educational intuitions. In the paper, also how the struggle and controversy between these power holding groups resulted in neglecting the education of the children was discussed.

Addressing the issues existing in Turkish education system would be a remedy for effective teaching approaches in order to prepare students for their life. As the Turkish education system is still experiencing dilemmas due to conflicts between pro-Westerners and anti-Westerners, it is crucial for schools leaders to understand what efforts regarding Westernization have affected this education system so that they would not easily destroy what has been build up for Turkish nation by such efforts. In addition, it is also important to know what issues are still prevalent in Turkish schools because of power struggles between the groups holding power. In short, in this literature analysis, we argue the conflicts due Westernization between proWesterners and anti-Westerners. Second, we discussed the Westernization efforts made in Turkey. Then, we explained criticism towards Westernization. Finally, we argued how the conflicts between pro-Westerners and anti Westerners resulted in military coups.

\section{Turkey's Westernization and Its Effects on Education}

The new education system in Turkey was shaped through the efforts made for modernization or Westernization. In particular, the Westernization of Turkey rests on three crucial historical turns: firstly, a series of continuous military defeats caused Turks to aggressively modernization as a way to militarily and technologically compete with other Western nations; secondly, the early designers of Turkish secular state relied heavily on French understandings and approaches. And thirdly, the reliance of Turkish political and educational elites on Western epistemologies and expertise thrusted Turkey onto a path of Westernization and Modernity.

Westernization refers to the establishment of a system based on science and technology in the life of a society where the principles of freedom and equality are adopted as the basis of human rights. This process also provides scientific solutions for the problems encountered in both individual and social life (Ergün, 1990). Westernization basically encourages developing countries to learn and then use what the West has found in science, technology, human rights, prosperity, and art (Başgöz, 2005). This section demonstrates how Turkey's Westernization efforts, which then have effected its education system.

The first efforts of Westernization in Turkey started during Ottoman State at the end of 18th century (Karpat, Durukan, \& Durukan 2002). At that time, Europe still was not at a stage of widely using the scientific applications for steam or mines. However, by the 19th century, Europe had substantial advancements in several areas including education. Such improvements made Turkish authorities believe that Europe was modern and that Turkey needed to do what was possible to reach to the same level of technology and education (Çetinkaya, 2002). The Westernization of Turkey aimed to make political changes in the individual life and social institutions in a democratic direction, improve industrialization for the economy and use science as a reference for higher order of thinking (Koçer, 1983). In efforts of creating a modern Turkish society, many Turkish political and educational elites had their trainings specifically from France during the Ottomans era. The French culture and language were considered as one of the modern languages of the time (Mignolo, 2009). The French culture and the use of their language effected Turkish state and its educational leaders about where to go in terms of obtaining their educational training during that time. For that reason, most of the educational leaders of that time preferred learning French language and culture (Akyüz, 2001).

During Westernization period, Turkish educational leaders ended up with spending many years in France and were affected by their cultures, literature, and living styles. However, such efforts of Westernization have remained superficial because Turkey was not ready for this goal as it did not have proper social, economic, scientific, and technological background. Nevertheless, at the beginning, the steps taken for Westernization somehow shaped Turkish education system; but it is hard to suggest whether the 
current education system of Turkey is still under the heavy influence of French culture as it used to be. Having said that, some of the factors affecting the Westernization efforts of Turkey include but are not limited to French Revolution and French ideology, foreign experts and educators, the views of Turkish educators and continuous military defeat (Ergün, 1990; Mardin, 2016).

\section{Continuous Military Defeat}

Modernization in Ottoman military was mainly based on military defeats and the visions of reformist sultans. After the progression of Ottoman military in Europe came to a complete end and being defeated in Wallachia (Eflak) in 1595, as known as the first reformist sultan, Osman II realized deformation in the military and felt a strong need for modernization and Westernization (Ergün, 1990). The sultan abolished some of the military units and created new laws for the dress code of military and scholars called Ulama in 1622. He believed that the success behind the European armies was all about their modernity (Çetinkaya, 2002). Therefore, the sultan may be considered as pro-Westerner. Eventually, the initiatives taken by the reformist sultan to make new reforms were not successful due to strong old and traditional views of the military personnel and Ulama. As a result, Osman II was killed by those who were against the new reforms and Westernization. After his death, the Ottomans continued to lose more of their lands (Akyüz, 2001).

Later on, the Karlowitz Treaty (Karlofça) was signed in 1699. By the treaty, it was officially accepted that the lands that the Ottoman Empire had obtained for centuries was coming out of hand. Many countries started open new fronts against the Ottoman Empire. Austria-Hungary and Venice from the west, Russia from the north, Iran from the east, France from the south, and the Egyptian army in support of Britain began to attack continually against the Ottoman territories. The Ottoman forces experienced more defeats resulting in loss of new territories (Ergün, 1990). After all these losses and several other issues including lack of motivation, the depletion of the treasury, the ruined land and the administrative system, and the complete destruction of the naval force, the Ottoman statesmen were forced to modernize everything which were failing for the moment as an effort of Westernization. Even though the military and scientific success behind Europeans created a sense of inferiority and admiration among Ottomans, the rapid and non-selective efforts of Westernization in failing areas did not result in success (Baykara, 1999).

\section{The Effects of French Revolution and French Ideology}

With the impact of the French Revolution in 18th century, many substantial changes occurred because of movement toward secularism and nationalism. There were strong friendship ties between the French and the Ottomans since Sultan Suleyman (The Magnificent) on many areas including commercial items and social and political areas. Therefore, the French Revolution easily affected the Ottomans. With the French Revolution, the disciplines taught in the institutions of higher education declared a war against religion while employing secular and nationalist ideologies (Başgöz, 2005; Mignolo, 2009). In terms of education, secular and nationalist thoughts of the French affected the Turks as well because along with Sultan Suleyman, some of the other Ottoman sultans also had ties with the French.

Some of the Ottoman sultans had relationships with France on the basis of having French educators to create a modern army. For instance, during the reign of Abdulhamid (1774-1789), the Grand Vizier Hamid Pasha brought specialists from France for training and technical rehabilitation of the Ottoman army (Koçer, 1983). During the French Revolution, Selim III was the Ottoman sultan. Because of the historical ties with France mentioned above, as another reformist sultan, Selim III took actions to transfer the advanced science and technology of French military as an effort of Westernization. During 1789-1807, Selim III, made relations with the king of France and sent one of his men called İshak Efendi to France in order to bring their military experts to train Ottoman soldiers as the sultan wanted to form a strong military against Austria and Russia. As soon as Selim III established a new military unit called Nizam-1 Cedid, he brought 15 French military experts to work on the modernization of the new military unit (Baykara, 1999). The westernization efforts of the Turks were in place not only before the French Revolution, but also after the Revolution. After the French Revolution more and more French educators came to Turkey to provide trainings in many areas including military and in the establishment of new modern schools. For this goal, for the establishment of naval school called Erkân-1 Harbiye Mektebi in 1845, an example of a French school model (ficole d'application d'fitatMajor) was used. When the Ottomans needed economic support of the West in 1856, more of the French impact became prevalent on Ottoman soils. In 1856, France forced the Ottomans to sign the Imperial Reform 
Edict (Islahat Fermani) to obtain several crucial rights including opening more French schools in Turkey. In these schools, they obtained rights to prepare instructional programs, which were the same programs as the ones in France. Students in these schools were fed by national and secular ideologies of France. The French influence in school curricula continued under new education laws and regulations. The imitation of these curricula even continued during the era of Turkish Republic. However, several years after the establishment of the republic, the influence of the French curricula faded away as the Turkish officials wanted to put more emphasis on the education system of the United States (Zürcher \& Gönen, 1999).

\section{Foreign Experts and Educators}

As for another Westernization effort especially European educators were invited. Educators and experts brought in from the West due to various topics have become another dynamic force that influenced Westernization in Turkish education system. They taught almost in all of the institutions in higher education including military schools of Turkey (Kaplan, 1999). They were first brought from France, and then educators from other European countries and the United States joined them. Some of them worked as teachers, some only provided reports on educational praxis (Turan, 2000). Turkish education system was easily adapted to Western teaching methodologies as there a heavy presence of the experts and educators from the West in Turkish schools during that time.

The oldest report provided to Ottomans by French experts in terms of Westernization was the one provided by French officer named De Rocheford. He wrote reports about the establishment of a foreign army unit in the Ottoman army in 1716. In 1732, some reports about printing press were also provided by French experts (Zürcher \& Gönen, 1999). Claude Alexandre Comte de Bonneval, who actually served in Ottoman army, brought in more French officers to serve after 1730s. In addition, after 1781, Baron de Tott, who came to Istanbul with French ambassador, did substantial work in naval academy. In 1798, at the request of Selim III, German officers joined the army's modernization with the arrival of Officer Von Goetze. In 19th century, Kari Ambrosso Bernard and Sigmund Spitzer, who were from Austria, were the instructors in Turkish medical schools. During the World War I, about 19 faculty members under the chairmanship of Franz Schmidt came to Turkey to teach at Istanbul University (Darülfünun) (Koçer, 1983).

In terms of Westernization efforts in Turkish education system, obtaining reports from foreign experts and educators continued a fashion of continuous trend even during the Republican era (After 1923) (Kaplan, 1999). For example, the work and effects of German experts on Turkish education continued during the time as 20 German educators worked in the establishment of the Ankara Institute of Higher Agriculture in 1928 (Akyüz, 2001). In addition, during 1933 and 1945, in Istanbul University about 120, and in Ankara University about 50 faculty members from Germany were teaching (Ergün, 1990; Koçer, 1983). As a result of Westernization efforts, the educators, who came to examine or write a report about the Turkish Education System included John Dewey (1924), P. Monroe (1924), Alfred Kühne (1925), G. Stiehler (1926), Omar Buyse (1927), Albert Malche (1932), B. Parker (1934), C. Mackenzie (1950), W. Dickerman (1951), J.J. Rufi, E. Tompkins, L. Beals, and K.V. Wafford (1952). Later on, educational experts from organizations such as ILO (International Labor Organization), UNESCO, and Ford came to Turkey to examine or write a report about the Turkish Education System as well (Büyükdüvenci, 1994; Ergün, 1990).

\section{Educational Training of Turkish Elite in Europe}

Turkish Students, who went to Europe for their educational training played crucial roles in explaining the education system of the West. These efforts helped to westernize the Turkish education system. Turkish elites went to most of the European countries to learn their education system in order to help creating a new and a modern Turkish education system (Adanal1, 2004). Several of the Turkish elites were sent to Europe by the Turkish Ministry of Education to learn about their education system (Akyüz, 2001). Among these educators includes an art teacher from Ankara School of Teachers, İsmail Hakkı Bey. He was sent to Europe to examine their education systems and write a report on experience and vocational school systems of Italy. As one of the student supervisors in Europe, Ahmet Hilmi Bey provided a report on German and Bulgarian schools. Vildan Hanım and Nizamettin Bey wrote another report on Danish educational system. Hüviyet Bekir Hanım wrote reports about the Austrian education system (Ergün ,1990; Zürcher \& Gönen, 1999). 
Many more Turkish educators, who had experience about the European school systems provided more reports to have created modern Turkish education system. For such purpose, Dr. Sabri, M. Cevdet, M. Coper, Z. Mesut, Dr. Necmettin Arif, Kemal Zaim, and Tunalı Hilmi Bey provided reports about the French education system. Turkish scholars such as Prince Sabahattin, Nafi Atuf, and Abdullah Cevdet Bey claimed that British and American education system was better than the French education system (Akyüz, 2001). Therefore, they wanted to influence the new Turkish education system based on British and American epistemologies. Some of the other Turkish scholars contended that German education system was better than ones in the rest of the West. For such aims, they translated the works of many German educators including G.Kerchensteiner, W. Förster, and E.Sprenger. In addition, they translated and published Kari Mathesius's “German Schools” in 1915 (Ergün, 1990; Kaplan, 1999).

The new and modern Turkish education system was affected by not only the countries mentioned above; it was also influenced by the education system of Sweden, Denmark, Czechoslovakia, Hungary, Poland, Italy, and Bulgaria. In respect with being affected by the European education system, Nafi Atuf and Ridvan Nafiz provided some reports on the Russian education system in 1926 to shape the new Turkish education system. As seen here, many experts, who was impressed by the European education system and episteme had a desire to have an effect in formation of the new and modern Turkish education system (Adanal1, 2004; Kaplan, 1999).

\section{Opinions of Turkish Elite about Western Education}

During the Ottoman era, Turkish education system employed traditional teaching approaches. The school types included sibyan schools, madrasah, and Enderun. Sibyan schools were providing elementary level education whereas Madrasa and Enderun were training qualified personnel for state administration (Başgöz, 2005; Mardin, 2005). According to some critiques, these schools focused mainly on religious education and did not provide adequate knowledge on the development of rational or critical thought (Berkes, 2013; İrem, 2004). Therefore, due to educational advancements in the West, the Ottoman authorities realized the need for a new education system that would shift from traditional teaching methodologies to the modern approaches similar to those in Europe (Akşin, 1980).

For creating a westernized education curriculum, many Turkish educators including Ziya Pasha, Namik Kemal, and Ali Suavi, who were under the impression of French epistemologies, thought that the mentality of Madrasa should be put aside in order to create a modern society (Akyüz, 2001). For similar objectives, Ziya Pasha translated the pedagogical work of J. J. Rousseau's "Emile" into Turkish. Namik Kemal brought the ideas of nationalism and freedom to the Turkish education. Selim Sabit Efendi, who studied in Paris between 1855 and 1861, wrote the first educational book based on the framework of western education thought in the Ottoman State (Zürcher \& Gönen, 1999). His work made a substantial impact on the placement of the new teaching method, teaching materials, and equipment in Turkish schools during that time. Ayşe Sıdıka Hanım wrote another book about the western education and teaching methods (Usul-ü Talim ve Terbiye Dersleri) in 1897. Similarly, Tirnovah Osman Nuri Bey wrote a book on the education system of Bulgaria in 1911 (Ergün, 1990; Parla, 1985). Writing about the education systems of the different countries created never ending debates on how effective education may be provided according to the new Turkish education system.

During the 2nd Constitutional Period (II. Meşrutiyet), between 1908 and 1920, Turkish educational thought had important debates on the translation and dissemination of Western pedagogical ideas. One of the important educators of the time, Emrullah Efendi made some recommendations about the new Turkish education system. He was known with his educational model called Tuba Tree Theory (Tuba Ağacı Nazariyesi). According to him, one of the most important tasks of the state was to protect education and knowledge (Adanall, 2004). Education starts top-down meaning that effective education is possible only by highly qualified educators in higher education (Ergün, 1990; Nişanc1, 2009; Parla, 1985). The views of Emrullah Efendi were one of the most important principles in the educational policy of the Committee of Union and Progress (Ittihat ve Terakki Cemiyeti), which was an influential power holding group of the time. As the ideologue of the committee, Ziya Gokalp shared similar educational ideas with Emrullah Efendi thinking that quality education should start from universities to elementary schools (Akşin, 1980). 
Ziya Gökalp was very influential both in the last period of the Ottomans and in the beginning of the Republic (Karataş, 2004). His thoughts on education influenced many scholars and politicians including the founder of the Turkish Republic, Mustafa Kemal Atatürk. Ziya Gökalp suggested that the new Turkish education system should include nationalist ideologies with contemporary teaching approaches (Akşin, 1980). Later on, the other two influential educators, İsmail Hakkı Baltacıŏlu and Mümtaz Turhan made contributions in designing the new education system. İsmail Hakkı Baltacioğlu, wrote boks and published an educational magazine called "New Man" (Yeni Adam) to fundamentally change the traditional ways of teaching and establish a new education system (Parla, 1985). He examined the problems associated with the old education system, focused on production, and created a new pedagogy called "İçtima-i Mektep Modeli" (Social School Model), which based on the principles of personality, environment, work, efficiency, and initiation. Mümtaz Turhan mainly studied cultural changes (Adanal1, 2004). He claimed that a group of Turkish elite must be trained to represent true science and follow the process of Westernization in the course of development and modernization. Therefore, for the training of the elites, he stressed the importance of a modern education system in Turkish universities. Eventually, one may claim that Turkish education system is still under the impression of Emrullah Efendi, Ziya Gökalp, and Mümtaz Turhan (Georgeon, 2000; Hanioglu, 2013).

This history of Westernization in Turkey has undoubtedly had implication for the common era. This history is important in understanding how knowledge and educational reform are framed, and what our cautionary notes might be as we navigate this reality. It would help us understand the tendency of some Turkish school leaders to describe educational reform almost completely in discourses of Westernization, while remaining completely oblivious to other bodies of knowledges that could enrich Turkish curriculum. In the remainder of the paper, we actually summarize critiques of Westernizatin in the past century. We follow this up with shifts in education since the 2016 attempted coup. We end the article with implications for educators who are also facing the hegemonic Westernized practices of education in students and communities they serve.

\section{Criticism towards Westernization since Ottomans}

Based on the phenomenon mentioned in previous paragraphs, Ottomans accepted being westernized due to problems that they could not resolve in education, military, and politics. The efforts made in terms of Westernization during Ottomans and the Republican era are undeniable. These efforts continue even today. However, besides those who are susceptive to Westernization, the numbers of those, who are opposed to Westernization movements in Turkey cannot be underestimated.

It is important to note that in addition to those who were in favor of the Westernization movements in Ottoman Empire, there were also opposed ones to the movement. By Westernization, Ottomans wanted to use the knowledge of the Western military, education, and technology in Turkish soil. For this purpose, during the reign of Ahmet III, a refugee from the West, İbrahim Müteferrika, brought the art of press to the Ottoman Empire (Karataş, 2004). Later on, elites who were in administrative positions such as Yirmisekiz Mehmet Çelebi and Nişli Mehmet Ağa were sent as ambassadors to various European countries. As this trend went on, the Western civilization's values for one's well-being effectively infiltrated in the Ottoman's ruler class (Nişanc1, 2009). This situation slowly turned into the rebellious actions of the lower and middle classes in Istanbul called Patrona Halil Rebellion during the Tulip Era in 1730 due to perceiving Westernization movement as a concession provided only to the rulers of the Empire. Similarly, the rebellious actions against the rulers of the Ottomans in regards to Westernization continued by Kabakci Rebellion, Kuleli Rebellion, and the Rebellion of March 31 (Hanioglu, 2013).

The efforts of Westernization during the reigns of Mahmut I (1730-1754), Abdulhamid I (1774-1789), and Selim III (1789-1807) were accelerated especially in military field (Koçer, 1983). These attempts were again interrupted by those who thought Westernization endangered the Ottoman culture. With Tanzimat in 1839, elites such as Mustafa Resit Pasha, Ali Pasha, and Fuat Pasha wanted to employ the West's military and administrative structure to modernize all institutions throughout the Empire. A well-known historian of the time, Cevdet Pasha stood against Westernization by claiming that by Tanzimat, the West, inversely interfered with the old Ottoman values. After that, with the support of Namik Kemal and Ziya Pasha, a 
systematic criticism began against Tanzimat because of its connection with the movement of Westernization (Kaplan, 1999).

The efforts of Westernization resulted in Reform Edict (Islahat Fermanı) in 1856 in Turkey. The Edict offered the term "Ottoman Citizenship" by claiming that from the time on, regardless of their religions, all individuals living on the Ottoman soils had the same privileges and rights (Büyükdüvenci, 1994). However, a group called the "New Ottomans" stressed that non-Muslims used such privileges with the support of the West and surpassed Muslims in finance, organizational behavior, and education (Akyüz, 2001). In addition, Cevdet Pasha continuously criticized the Edict due taking all important privileges from the Muslims for the sake Westernization. By 1890s, notable writers including Ahmet Mithat, Ömer Seyfettin, and Recaizade Mahmut Ekrem also criticized the predominant existence of Westernization on the life and culture of Turkish people (Ergün, 1990).

During the 2nd Constitutional Period (II. Meşrutiyet Dönemi), the efforts made for Westernization continued in Turkey. After 1908, an Islamist poet, Mehmet Akif Ersoy, suggested that even though the culture of the West showed its dominance in many aspects of the life of the people, the Turks should find a way to preserve their culture while adapting to the West's technique rather than its ideology and life style (Başgöz, 2005). He emphasized that basically the Turks should stop imitating the Western values. After Mehmet Akif Ersoy's objection to the West's ideology, an Islamist movement took place to resist to the West's cultural and ideological dominance.

Later on, during the Republic Era, it is important to note that Ataturk, the founder of Turkish Republic was in favor of Westernization. However, right after his death, powerful people holding positions in the government claimed that Westernization was nothing other than imitating the ideology and culture of the West (Mardin, 2016). This criticism nourished since 1940s from the idea that the movement of Westernization betrayed the core values of Islam and the Republic. Although most critics were grew up during the era of Ataturk, later on, by 1960s, they started thinking that the process of Westernization in Turkey seemed quite superficial and that it was all about the imitation of the West's own values (Akyüz, 2001). Especially after 1960s on, the tension between pro-Westerners and anti-Westerners grew more and resulted in military coups, which had substantial adverse impacts on democracy, economy, and educational policies.

\section{The Effects of Coups on Turkish Education System}

Many Turkish educators and politicians went to Europe to obtain educational training or knowledge about the European education system in order to build a new, modern, and westernized Turkish education system (Mardin, 2016). They took effective steps to make substantial contributions to create new curricula that would be for the benefits of the Turkish students. However, especially after the establishment of the Republic, the debate between pro-Westerners and anti-Westerners has continued. Pro-Westerners claim that the education system of Turkey should include a westernized, modern, and secular education whereas antiWesterners or conservatives suggest that the education system should be traditional and must have religious values of the Turkish people (Gulalp, 1999). Even though the debates on the Turkish education system should be considered as an attempt to better the education system, the controversy between pro-Westerners and anti-Westerners eventually resulted in several military coups during the modern era of Turkey (Aydinli, 2009). These coups took place in 1960, 1971, 1980, 1997, 2007, and 2016. Among these, the coup of 1997 was one that mostly effected the Turkish education policy, therefore that coup is explained in details in the paper. Turkey has been able to operate democratic elections on regular basis since 1946 despite shortly survived military terms. The winner of the elections was mainly a socialist party. The party employed secular nationalist ideologies and imposed such views throughout all government institutions. Especially the institutions of the Turkish military were the strong defenders of the secular nationalist ideology (Aydinli, 2009). However, during 1990s, some social groups in favor of religious brotherhood over nationalism increased their impact and visibility by resisting the authoritarian and exclusionary politics of secular nationalism (Mardin, 2005). Later, they were represented by Welfare Party (RP) and won their first election in 1994. After the local elections, with the support of the same social group, Welfare Party came as number one party in general elections as well in 1995. The party's program was structured around the idea of "Just Order". Later on, in 1996, Welfare Party made a coalition government with True Path Party (DYP), which 
was a central right wing party. The success of Welfare Party eventually irritated some periphery such as secular nationalists (Gulalp, 1999). The cadres of secular nationalists took every possible action, mainly nondemocratic praxis to put pressure on and discredit the successful movement of Welfare Party. The efforts of secular nationalists appeared as in having military tanks showing off on the streets of Ankara, the capital city of Turkey, on February 28, 1997 to give strong messages to Welfare Party and its social circles (Nasr, 2005). This attempt was then called a post-modern coup.

Supporting the efforts of secular nationalists, the National Security Council (MGK) immediately issued 18 recommendations for the incumbent Government (Erdoğan, 2015). The recommendations made by National Security Council mainly dictated that the principles of secularism should be enforced, and current laws should be changed to serve such principles. These recommendations put a lot of attention to the importance secularism and that a democratic and modern Turkey was possible by practicing the acts of secularism in all aspects of daily practices (Nasr 2005). As a result, these recommendations had a tremendous impact on the educational practices in Turkey.

Basically, the National Security Council took precautions to create more paths for the advancement of secularism and limit the progression of the religious ideology in the nation (Mardin, 2016). After the postmodern coup, the religious schools called Imam-Hatip schools started not having enough students. Students did not want to enroll in these schools because they were discredited by the recommendations of the National Security Council (Gürkan, 2011). In Turkey, during that time, after students graduate from high school, they take a university entry exam to be placed in certain programs. When students' scores are calculated for university programs, their scores from university entry exam plus a coefficient are multiplied by their transcript scores. So, this coefficient was lowered too much for Imam-Hatip schools after postmodern coup. Therefore, students preferred enrolling in schools with higher coefficients. Although, ImamHatip schools had difficulty during that time, currently, the party (AKP) in power has been criticized by secular Turks for opening more of such schools to propagate the religious thoughts throughout Turkey. The recommendations of the National Security Council also included banning females from wearing Islamic clothes (Hijab) in government institutions including public universities (Aydinli, 2009). After that reinforcement, many female students in universities had to give up on their educational rights and discontinued to go to university in order to protect their religious beliefs (Gülmez, 2014; Nasr, 2005).

\section{DISCUSSION AND CONCLUSIONS}

In this paper, we have argued the effects of Westernization efforts and how the power holding groups use these efforts on their behalf to have authority over governmental institutions and change the education policy of Turkey according to their ideology. Quijano's notion of Coloniality was used to explain how people, who had governmental authorities used Westernization to have a control over the Turkish education policy. In the paper, firstly, we argue why the conflicts due Westernization arise between pro-Westerners and anti-Westerners and how this situation effects the education policy of some societies in the world. Secondly, we discussed the Westernization efforts made in Turkey. Thirdly, we explained criticism towards Westernization since the Ottoman period. Lastly, we argued how the conflicts between pro-Westerners and anti-Westerners ended up as in military coups.

The conflict between pro-Westerners and anti-Westerners has the essence of colonial ideology as it includes pressure and oppression over the items such as economy, culture, and education policy of the societies. Confirming this, in Mexico, a Western influenced education program neglected to include the cultural themes and languages of the indigenous people in the program (Meyer, 2017; Rogoff, 2003). This situation is not different in Muslim nations as well. After the colonial expansion of the West into the Muslim nations, the Muslims had difficulty to adapt themselves to the Western values. Especially after the stakeholders wanted to westernize their education systems, they experienced confrontations with the indigenous Muslim people. In most cases, the indigenous people were controlled by their centralized governments and experienced oppression (Herrera, 2004). The educational leaders, who have control over the educational institutions need to include the values of the indigenous while westernizing or modernizing the school systems (Schoombee \& Mantzaris, 1986). Neglecting the cultures, languages, or worldviews of the indigenous people may end up creating protests, disobedience, and having them seek alternative schools, which may be quite expensive and exhausting. 
Even though the conflicts between pro-Westerners and anti-Westerners were quite obvious, it is important to understand the reasons behind the efforts of Westernization. Several factors forced Turkish leaders to employ science and technology of the West in accordance with the Westernization of Turkey. These factors included military defeat, French Revolution and French ideology, the success of foreign experts and educators, and the perceptions Turkish educators, who had admirations for the European culture, science, and technology (Parla, 1985; Nişanc1, 2009). As Turkey had strong relationships with France since the Ottoman era, firstly, the developments in France affected Turkish leaders of that time. Turkey sent its political and educational leaders to Europe to obtain educational trainings and learn about Europeans' science, technology, human rights, prosperity, education, and art (Başgöz, 2005; Ergün, 1990).

After the Turkish educators were trained in the West, they wanted to impose the culture and epistemology of the country they admired into the Turkish education system. This approach eventually created problems in Turkish education policy as the cultural values and the ideology of the West were not exactly compatible with the ones in Turkey (Başgöz, 2005; Hanioglu, 2013; Nişanc1, 2009; Turan, 2000). It is crucial to indicate that the disagreement about Turkish education policy was evident not only between proWesterners and anti- Westerners but also among pro-Westerners themselves (Zürcher \& Gönen, 1999). They were having dilemmas on deciding to accommodate which education system of the West may be the best fit for the Turkish education system. Some examples included the education systems of France, Germany, Italy, Austria, or Bulgaria (Akyüz, 2001; Kaplan, 1999). As the conflict between these groups, who controled authority in Turkey grew, at some point, they forgot or tended to neglect the essence of the cultural values and worldviews of the indigenous Turkish people (Hanioglu, 2013). Instead of just focusing on the education systems of the West, it would be more beneficial for these stakeholders in education to formulate and then execute an educational plan that include both educational praxis of the West and Turkey.

As for those who were in favor of Westernization, there were also elites, who were against the movement of Westernization in Turkey. There were people, who were opposing to Westernization during the reigns of Ahmet III, Mahmut I, Abdulhamid I, and Selim III. They criticized reforms made during Tanzimat, Reform Edict, and the 2nd Constitutional Period (Karataş, 2004). In some cases, people were killed due to the confrontations between government authorities and the oppositional rebels (Nişanc1, 2009). Some examples of these confrontations were Patrona Halil Rebellion, Kabakci Rebellion, Kuleli Rebellion, and the Rebellion of March 31 (Hanioglu, 2013). The main reason behind these conflicts included the dominant presence of western values infiltrating into Turkish traditional values. In these events it is seen that the opposing groups showed a firm stance against Western values.

The conflicts between pro-Westerners and anti-Westerners continued even in the modern era of Turkey. Some of the leaders in power wanted to use western ideologies to shape Turkish politics and education system. This method of shaping politics and education encountered severe protests of the indigenous Turkish people. The controversy between government authorities and their opponents resulted in several military coups (Aydinli, 2009; Mardin, 2016). Among these, the coup of 1997 was the one, which mostly impacted the Turkish educational policy. As known as "modern coup", after the coup of 1997 the importance of secularism, which was imported from the West was emphasized in all educational and government institutions (Erdoğan, 2015; Nasr, 2005). The main goal of this coup was to create oppression on religious and indigenous people of Turkey. Especially female students were prohibited from wearing hijab in public schools. Many of these students had to give up on their educational rights and quit going to their university (Aydinli, 2009; Gülmez, 2014). As seen here, the wrong use of Western ideologies took educational privileges away from Turkish students and had a deeply inverse impact on their lives and educational policies of Turkey.

In the final analysis, the dilemmas stand still in Turkish education system because of the conflicts between pro-Westerners and anti-Westerners (Sönmez, 1997). As the leaders, who have control over government institutions focus on exhibiting how powerful they are, the issues in Turkish education system still await for effective solutions. Several main issues existing in Turkish education include having same curricula for everyone, teacher-centered teaching, oppression due to being forced to take the same courses, fear towards teachers and school administrators, and assignment of too much homework (Çınar, 2012; Topçu, 2006). Therefore, it is crucial to point out that the main goal of people in power should be developing education policies that enhance critical thinking skills among students (Dewey 2007). The school leaders 
need to develop critical consciousness and the practice of freedom as noted by Freire (2005). The authorities also should help creating a school setting that is based on a principle that prioritizes students and studentship (Gökalp, 2005). Basically, the education system in Turkey should become part of a system where students discover their skills. That way, the students would be able to make their life more meaningful (Fromm, 2003). Therefore, the education system of Turkey should be saved from nonsense arguments between pro-Westerners and anti- Westerners in order to find effective solutions to the actual problems of the education system of Turkey.

\section{REFERENCES}

Adanalı, A. H. (2004). Ziya Gökalp'in eğitim felsefesi ve yüksek eğitim hakkındaki görüşleri. Ankara Üniversitesi Illahiyat Fakültesi Dergisi, 45(1), 57-70.

Akşin, S. (1980). 100 Soruda Jön Türkler ve İttihat ve Terakki (p. 311). Gerçek Yayınevi.

Akyüz, Y. (2001). Türk eğitim tarihi (başlangıçtan 2001'e)[History of Turkish education (from the beginning to 2001)]. İstanbul: Alfa Yayınları.

Aydinli, E. (2009). A paradigmatic shift for the Turkish generals and an end to the coup era in Turkey. The Middle East Journal, 63(4), 581-596.

Aygün, M. (2014). "Yeni" neyi temsil ediyor? yeni fetişizmi ve "yeni Türkiye" mitleri [What does "new" stand for? fetishizing new and the myths of "new Turkey"]. Sosyologca. 8, 55-66.

Başgöz, İ. (2005). Türkiye'nin eğitim çıkmazı ve Atatürk (p. 126). Istanbul: Pan.

Baykara, T. (1999). Osmanlılar'da medeniyet kavramı ve ondokuzuncu yüzyıla dair araştırmalar, II. Baskı, Akademi Kitabevi, İzmir.

Berkes, N. (2013). Introduction. In The Development of Secularism in Turkey (pp. 35-54). Routledge.

Bloom, B. S. (1995). Insan nitelikleri ve okulda öğrenme [Human characteristics and school learning]. Translator: D. A. Özçelik. İstanbul: Milli Eğitim Bakanlığı Yayınları.

Büyükdüvenci, S. (1994). John Dewey's impact on Turkish education. Studies in Philosophy and Education, 13(3-4), 393-400.

Cook, B. J. (2000). Egypt's national education debate. Comparative Education 36(4), 477-490.

Çetinkaya, B. A. (2002). Modern Türkiye'nin felsefi kökenleri. Cumhuriyet Üniversitesi Illahiyat Fakültesi Dergisi, 6(2), 65-92.

Çınar, İ. (2012). Neden ve nasıl mankurtlaştırllıyoruz? [Why and how we are enslaved?]. İstanbul: IQ Kültür Sanat Yayıncilık.

Dewey, J. (2007). Deneyim ve eğitim [Experience and education]. Translator: S. Akıllı. Ankara: ODTÜ Yayıncilik.

Erdoğan, B. (2015). Reproduction of post-colonial mental codes in modern Turkey. Istanbul Gelisim University Journal of Social Sciences, 2(1), 125-141.

Ergün, M. (1990). Türk eğitim sisteminin batılılaşmasını belirleyen dinamikler. Atatürk Araştırma Merkezi Dergisi, 17, 453-457.

Ferrer, F. (2014). Özgür eğitim: modern okulun kökenleri [The origin and ideals of the modern school]. Translator: H. Şahin. İstanbul: Pales Yayınları.

Foucault, M. (2003). Seçme yazılar 4: iktidarm gözü [Selected essays 4: the eye of the power]. Translator: I. Ergüden. İstanbul: Ayrıntı Yayınları.

Freire, P. (2005). Education for critical consciousness. London: Continuum.

Fromm, E. (2003). Sahip olmak ya da olmak [To have or to be]. Translator: A. Arıtan. İstanbul: Arıtan Yayınevi. 
Georgeon, F. (2000). Osmanl1-Türk modernleşmesi 1900-1930 [The Modernization of Ottoman Turkish], trans. Ali Berktay. Istanbul: YKY.

Gökalp, Z. (2005). Türk terbiyesi [Turkish education]. Editor: Y. Toker. İstanbul: Toker Yayınları.

Gulalp, H. (1999). Political Islam in Turkey: The rise and fall of the Refah Party. The Muslim World, 89(1), 2241.

Gülmez, İ. (2014). 28 Şubat 1997 Askeri darbesi ve Türk eğitim sistemine etkileri (Unpublished Thesis). Atatürk University, Erzurum, Turkey.

Gürkan, H. (2011). 28 Şubat sürecinin Türk eğitim sistemine etkileri ve iktidar muhalefet partilerinin tutumu. (Unpublished Thesis). Çukurova University, Adana, Turkey.

Hanioglu, S. (2013). Blueprints for a future society: Late Ottoman materialists on science, religion, and art. In Late Ottoman society (pp. 50-138). Routledge.

Herrera, L. (2004). Education, Islam, and modernity: Beyond Westernization and centralization. Comparative Education Review, 48(3), 318-326.

İnal, K. (1996). Eğitimde ideolojik boyut -yazılar- [The ideological dimension of education -essays]. Ankara: Doruk Yayıncilık.

İem, N. (2004). Undercurrents of European modernity and the foundations of modern Turkish conservatism: Bergsonism in retrospect. Middle Eastern Studies, 40 (4), 79-112.

Kaplan, İ. (1999). Türkiye'de milli eğitim ideolojisi. İstanbul: İletişim Yayınları.

Karataş, M. (2004). Küreselleşme, kültür, eğitim ve Ziya Gökalp. Sakarya Üniversitesi Eğitim Fakültesi Dergisi, $8,64-71$.

Karpat, K. H., Durukan, A. Z., \& Durukan, K. (2002). Osmanlı modernleşmesi: toplum, kuramsal değiş̧im ve nüfus. İmge Kitabevi.

Kızılçelik, S. (2015). An Evaluation of the Turkish Education System outside the Conflict between Old and New. Eurasian Journal of Educational Research, 59, 149-163.

Koçer, H. A. (1983). İlkokul Öğretmeninin Yetiştirilmesi 1923-1980. Cumhuriyet Döneminde Eğitim MEB Yayımi, (91).

Mardin, Ş. (2005). Turkish Islamic exceptionalism yesterday and today: Continuity, rupture and reconstruction in operational codes. Turkish Studies, 6 (2), 145-165.

Mardin, Ş. (2016). Jön Türklerin siyasi fikirleri 1895-1908. İletişim Yayınları.

Mayo, P. (2011). Gramsci, Freire ve yetişkin eğitimi: dönüştürücü eylem firsatları [Gramsci,Freire, and adult education: possibilities for transformative action]. Translator: A. Duman. Ankara: Ütopya Yayınevi.

Meyer, L. M. (2017). Resisting Westernization and school reforms: Two sides to the struggle to "communalize" developmentally appropriate initial education in indigenous Oaxaca, Mexico. Global Education Review, 4(3), 88-107.

Mignolo, W. D. (2009). Epistemic disobedience, independent thought and decolonial freedom. Theory, Culture $\mathcal{E}$ Society, 26 (7-8), 159-181.

Nasr, S. V. R. (2005). The Rise of" Muslim Democracy". Journal of Democracy, 16(2), 13-27.

Nişancı, Ş. (2009). İttihat Terakki politikalarında pozitivizmin etkisi ve eleştirel bir yaklaşım. Bilgi Sosyal Bilimler Dergisi, 2, 19-49.

Parla, T. (1985). The social and political thought of Ziya Gökalp: 1876-1924 (Vol. 35). Brill.

Quijano, A. (2000). Coloniality of power and Eurocentrism in Latin America. International Sociology, 15(2), 215-232.

Rogoff, B. (2003). The cultural nature of human development. New York: Oxford University Press. 
Schoombee, G. F., \& Mantzaris, E. A. (1986). Attitudes of South African Indians towards Westernization and its effects on their family life: A pilot study. South African Journal of Sociology, 17(1), 17-21.

Sönmez, V. (1997). Sevgi eğitimi [The education of love]. Ankara: Anı Yayınları.

Topçu, N. (2006). Türkiye'nin maarif dâvası [The problem of education in Turkey]. Editor: E. Erverdi \& İ. Kara. İstanbul: Dergâh Yayınları.

Turan, S. (2000). John Dewey's Report of 1924 and his recommendations on the Turkish educational system revisited. History of Education, 29 (6), 543-555.

Zürcher, E. J., \& Gönen, Y. S. (1999). Modernleşen Türkiye'nin tarihi. İletişim Yayınları. 